\title{
Sudden Death in Sickle Cell Disease: An Autopsy Diagnosis
}

\author{
${ }^{1}$ Nanditha Sheshanna, ${ }^{2}$ Gurpreet Sethi, ${ }^{3}$ Jyothi A Raj, ${ }^{4}$ Sumitha M Prakash, ${ }^{5}$ Sharmila P Surhonne
}

\begin{abstract}
Sickle cell disease is a common hereditary hemoglobinopathy with high prevalence in the central and northeastern regions of India. A 24-year-old male patient with 3 days' history of fever was brought dead to the hospital. Morphology showed clogging of blood vessels with sickled red blood cells (RBCs) in all the organs, and an autopsy diagnosis of sickle cell disease was made. As the cause may not be obvious in many cases, most patients remain undiagnosed. It is important to note the circumstances of death, gross finding, and histopathology, with hemoglobin electrophoresis if available, during autopsy to arrive at the diagnosis. This case is presented here to highlight this fact and draw attention to its pathology.
\end{abstract}

Keywords: Autopsy, Histopathology, Sickle cell disease, Sudden death.

How to cite this article: Sheshanna N, Sethi G, Raj JA, Prakash SM, Surhonne SP. Sudden Death in Sickle Cell Disease: An Autopsy Diagnosis. J Med Sci 2017;3(4):113-115.

Source of support: Nil

Conflict of interest: None

\section{INTRODUCTION}

Sickle cell disease is a common hereditary hemoglobinopathy caused by point mutation in $\beta$-globin that promotes polymerization of deoxygenated hemoglobin leading to red cell distortion, hemolytic anemia, microvascular obstruction, and ischemic tissue damage. ${ }^{1}$

Sickle cell disease has a high prevalence in India, especially in the central and the northeastern regions. The major clinical manifestation among homozygotes in India is vaso-occlusion with the highest incidence during monsoon season. ${ }^{2}$

\section{CASE HISTORY}

A 24-year-old male patient with 3 days' history of fever was brought dead to the hospital. Only significant

\footnotetext{
${ }^{1,2}$ Postgraduate Student, ${ }^{3}$ Professor, ${ }^{4}$ Assistant Professor ${ }^{5}$ Professor and Head

1-5Department of Pathology, RajaRajeswari Medical College \& Hospital, Bengaluru, Karnataka, India

Corresponding Author: Jyothi A Raj, Professor, Department of Pathology, RajaRajeswari Medical College \& Hospital Bengaluru, Karnataka, India, e-mail: jyoki255@yahoo.in
}

findings reported on postmortem were fluid in the pleural cavity and frothy, blood-tinged exudate from lungs.

\section{MORPHOLOGY}

Gross: Organs received were heart, part of brain, parts of both kidneys, part of liver with attached flap of diaphragm, and part of both lungs, none of which showed any gross pathology. Spleen was enlarged in size measuring $11.5 \times 8.0 \times 3.0 \mathrm{~cm}$, weighing $250 \mathrm{gm}$, and showed thickened capsule (Fig. 1).

\section{MICROSCOPY}

Lungs showed dilated alveolar spaces with extensive pulmonary edema and alveolar capillaries clogged with sickled RBCs (Fig. 2).

Sinusoids and blood vessels in the liver were congested and clogged with sickled RBCs. Hepatocytes showed ballooning degeneration in some lobules (Fig. 3).

Spleen showed thickened capsule and broad fibrous septae. Congestion and clogging of blood vessels with sickled RBCs was noted. Areas of hemorrhage and siderofibrotic nodules were seen (Gamna-Gandy bodies) (Fig. 4).

Glomeruli in both kidneys showed increased capillaries with congestion. Many nephrons showed global sclerosis of glomeruli and atrophic tubules. Cloudy change was noted in the tubular epithelium. Interstitium

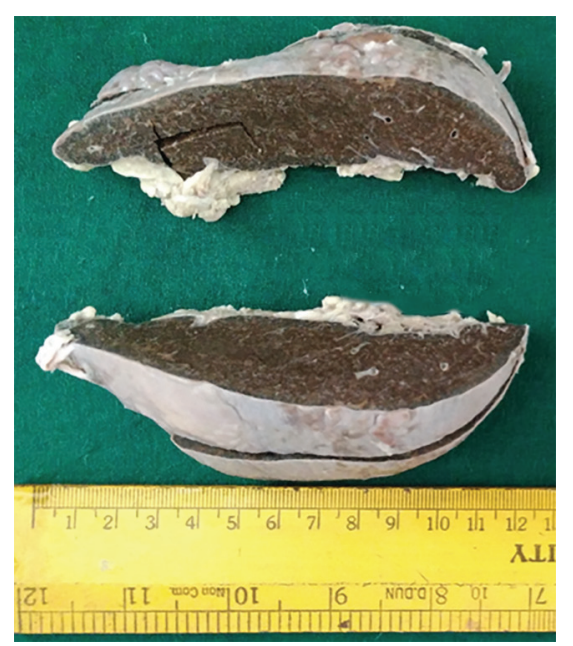

Fig. 1: Sickle cell disease: specimen of enlarged spleen weighing $250 \mathrm{gm}$ 


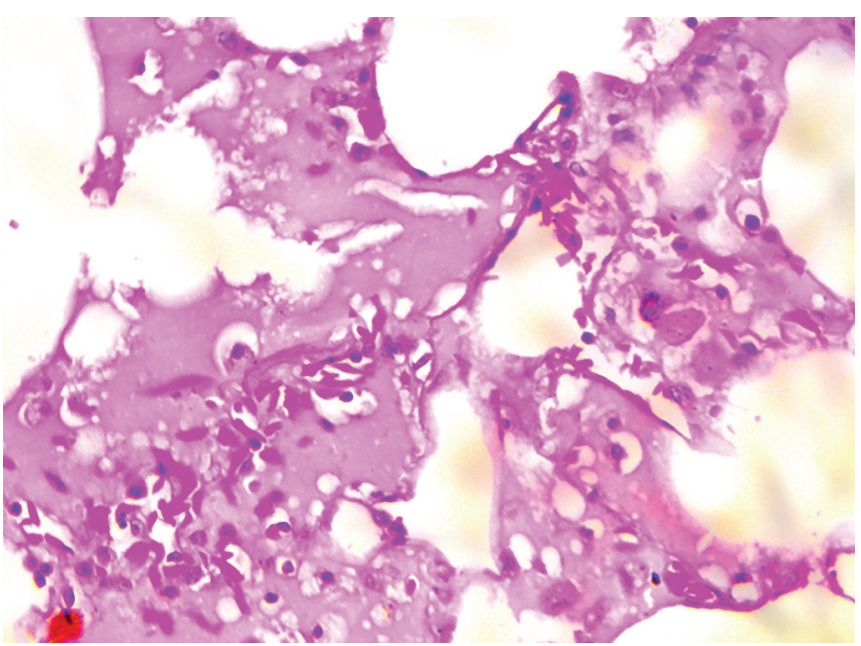

Fig. 2: Sickle cell disease: lung showing dilated alveolar spaces with extensive pulmonary edema, and sickled RBCs in alveolar capillaries (hematoxylin and eosin, 40x)

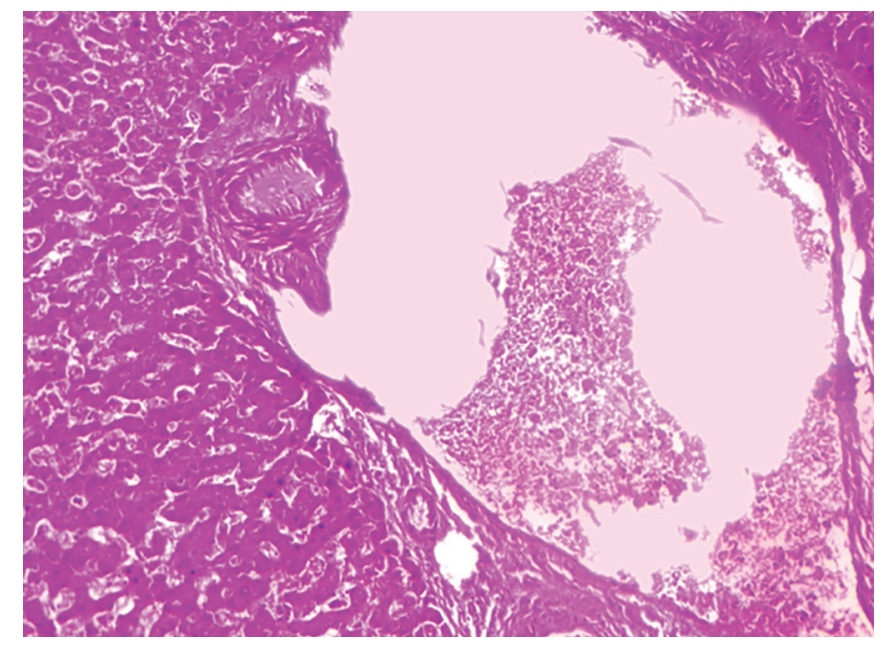

Fig. 3: Sickle cell disease: liver sinusoids and blood vessels clogged by sickled RBCs (hematoxylin and eosin, 40x)
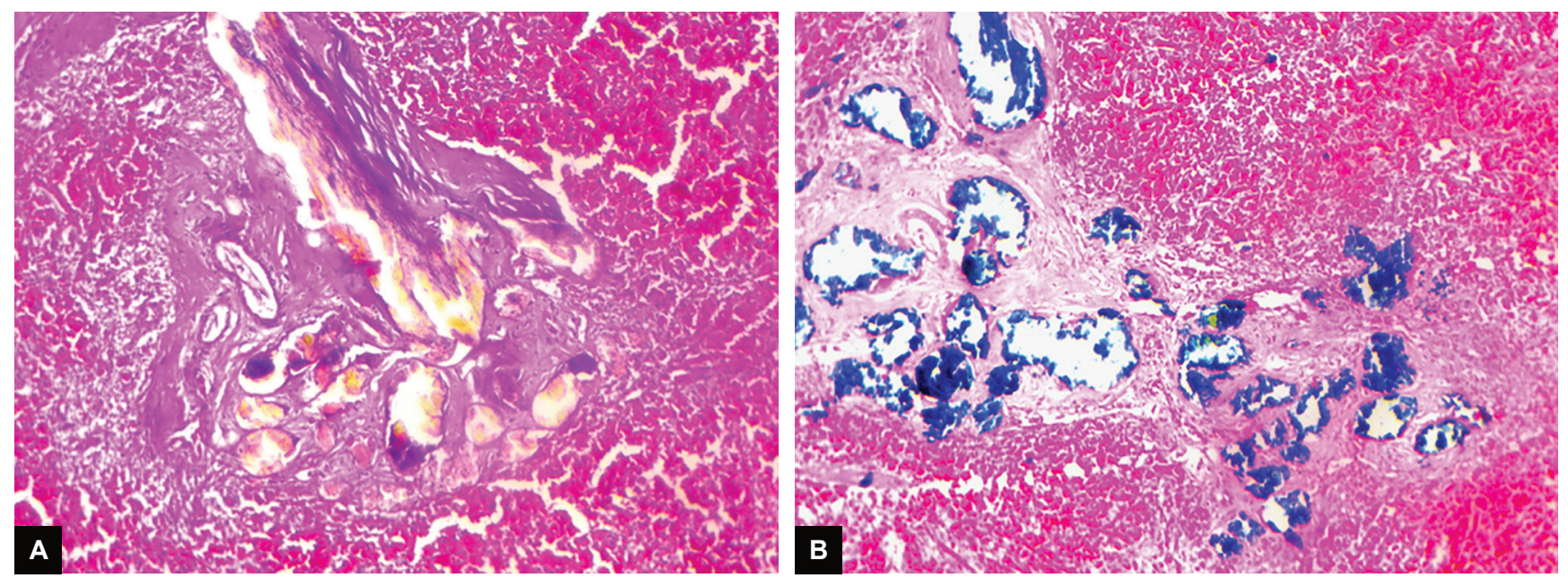

Figs 4A and B: Sickle cell disease: (A) splenic congestion and Gamna-Gandy bodies (hematoxylin and eosin, 40x); (B) splenic congestion and Gamna-Gandy bodies (Perl stain, 40x)

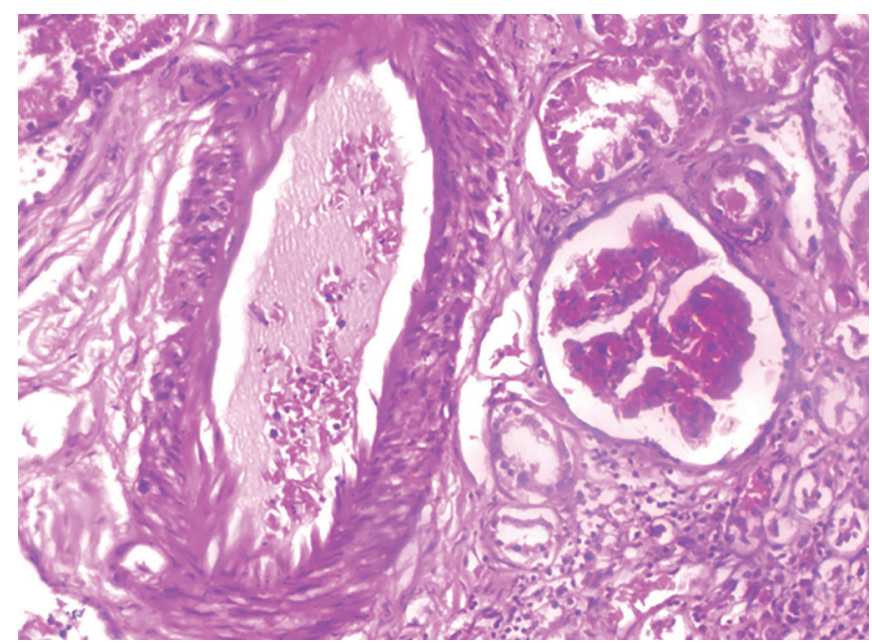

Fig. 5: Sickle cell disease: sickled RBCs in glomerular capillaries (hematoxylin and eosin, 20x)

showed fibrosis, focal inflammatory infiltrate, and edema. Vessels showed congestion and clogging by sickled RBCs (Fig. 5).

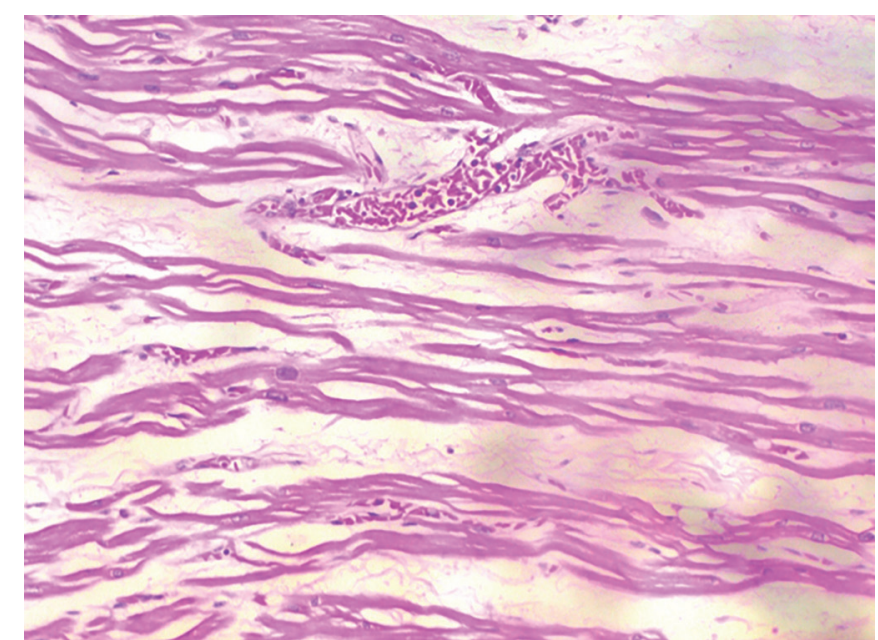

Fig. 6: Sickle cell disease: myocardium shows sickled RBCs in capillaries (hematoxylin and eosin, 20x)

Sickled RBCs were seen clogging the capillaries of myocardium and brain (Figs 6 and 7). Similar morphology was also noted in the diaphragm. 


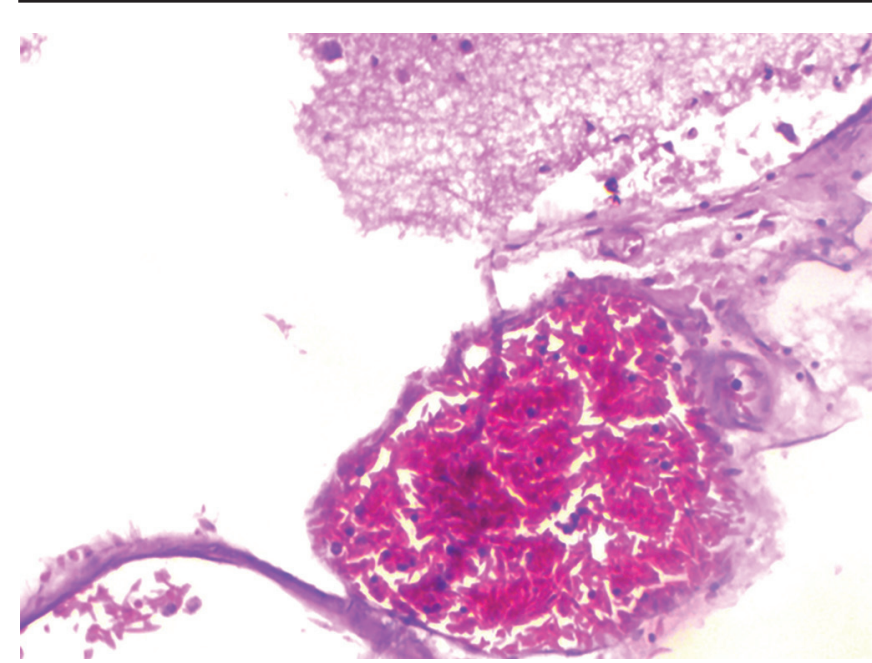

Fig. 7: Sickle cell disease: glial tissue with sickled RBCs in the vascular spaces (hematoxylin and eosin, 40x)

Correlating the above histologic findings with the circumstances of death, an autopsy diagnosis of sickle cell disease was made.

\section{DISCUSSION}

Sickle hemoglobin is highly prevalent in India, particularly among the tribals of central and northeastern states which fall in the sickle cell belt. Sickle cell disease is one of the most common monogenic disorders globally with an autosomal recessive inheritance. The primary pathophysiology is based on the polymerization of deoxy hemoglobin $(\mathrm{Hb}) \mathrm{S}$ with formation of long fibers within RBCs causing a distorted sickle shape, which eventually leads to increased hemolysis and vaso-occlusion of sickle red cells. However, the clinical presentation of sickle cell disease patient is extremely variable, and there are several events that may trigger vaso-occlusion, red cell dehydration, and inflammatory events. ${ }^{3,4}$

Hypoxia due to exertion induces a chain of events in a person with sickle cell anemia that causes sickling, leading to vascular occlusion potentiating hypoxia and culminating in sudden death. Similarly, infections, fever, anxiety, abrupt changes in body temperature, or hypertonic dyes are precipitating factors for sickle cell crisis. But in many cases, no cause is obvious. ${ }^{4}$

The common clinical presentation in India is splenomegaly, which is a characteristic feature due to reticuloendothelial hyperplasia secondary to increased red cell destruction. Tendency for increasing splenic size is also associated with higher $\mathrm{HbF}^{5,6}$

Our patient had a short history of fever lasting for 3 days and was brought dead to our hospital. This fits the description of sickle cell crisis. Differentiating whether the sickling occurred in antemortem or postmortem period is difficult as many of these processes with hypoxia and acidosis do occur during the perimortem period causing intravascular sickling like that in sickle cell disease. ${ }^{4}$

\section{CONCLUSION}

Sickle cell crisis is one of the causes of sudden unexplained death. Manifestations of sickle cell disease in Indian population are milder, predominantly because of high $\mathrm{HbF}$ levels. This characterizes the late age of presentation, more asymptomatic patients, less frequency of vaso-occlusive crisis, and low mortality. Hence, most of the patients remain undiagnosed. It is important to note the circumstances of death, gross finding, histopathology, and hemoglobin electrophoresis during autopsy. This case is presented here to highlight this fact and draw attention to its pathology.

\section{ACKNOWLEDGMENTS}

The authors would like to thank the Department of Forensic Medicine and Toxicology, RajaRajeswari Medical College \& Hospital, Bengaluru, Karnataka, India.

\section{REFERENCES}

1. Kumar, V.; Abbas, AK.; Aster, JC. Chapter 14 in Robbins \& Cotran: pathologic basis of disease. Vol. 1. 9th ed. New Delhi: Elsevier; 2015. pp. 635-638.

2. Tewari S, Rees D. Morbidity pattern of sickle cell disease in India: a single centre perspective. Indian J Med Res 2013 Sep;138(3):288-290.

3. Colah RB, Mukherjee MB, Martin S, Ghosh K. Sickle cell disease in tribal populations in India. Indian J Med Res 2015 May;141(5):509-515.

4. Shrigiriwar MB, Ghormade PS, Tingne CV. Death due to sickle cell anaemia: autopsy diagnosis. J Indian Acad Forensic Med 2013 Oct-Dec;35(4):383-385.

5. Pillai LV, Husainy S, Gosavi S, Vidya N. Sudden unexpected death in an undiagnosed sickle disease. Indian J Crit Care Med 2005 Apr;9(2):92-95.

6. Shukla RN, Solanki BR, Parande AS. Sickle cell disease in India. Blood 1958 Jun;13(6):552-558. 